\title{
The Existence of the Sangeh Village Credit Institution (LPD) in Supporting the Village Community Economy
}

\author{
I Nyoman Putu Budiartha ${ }^{1}$, I Putu Suwantara ${ }^{2}$, A.A Sagung Laksmi Dewi ${ }^{3}$, Ni Made \\ Puspasutari Ujianti ${ }^{4}$, Desak Gde Dwi Arini ${ }^{5}$, I Made Aditya Mantara Putra ${ }^{6}$ \\ Faculty of Law, Universitas Warmadewa $a^{1,2,3,4,5,6}$ \\ \{ budiartha59@gmail.com \}
}

\begin{abstract}
Sangeh is one of the villages in the Abiansemal Sub-district, Badung Regency, Bali Province, which is famous for its tourist destinations. However, for continuous existence as a tourist destination, a lot of development and tourism support business sectors need to be established, which requires lots of money. Therefore, the Village Credit Institution (LPD) and Rural Credit Bank (BPR) were established as of the Microfinance Institutions to assist in tourism to help in providing capital. However, normatively, the establishment and ownership of BPRs in Traditional Villages are in conflict with the provisions of Article 4 of the OJK Regulation Number 20 / POJK.3 / 2014.
\end{abstract}

Keywords: Village Credit; Business Sector; Rural Credit Bank

\section{Introduction}

Bali is a province that drives its economy not by the power of natural resources, but by means of cultural resources. Like natural resources, culture as an economic resource also requires maintenance. The maintenance of Balinese culture as an economic resource is fully the responsibility of community the Pakraman village. Balinese culture is the spirit and basic capital of tourism in Bali.

In 1984, the Provincial Government of Bali came up with an idea to help Pakraman village carry out its cultural functions. With the Governor's Letter Number 972 of 1984, dated November 1, 1984 regarding Village Credit Institutions, the Provincial Government of Bali sparked the idea of establishing Village Credit Institutions in every customary village (now called Desa Pakraman). The Lembaga Perkreditan Desa (hereafter LPD) or Village Credit Institutions aims to make Krama Desa Pakraman prosper. Besides that, LPD aims to improve the economy of Pakraman village (Raydika, 2013). Ensuring the realization of the welfare of the customary law community which is Krama Pakraman Village. So this is what causes the LPD to be different from other financial businesses that are profit-oriented, even though there are similarities in collecting and distributing funds.

Sangeh Village is one of the villages located in Abiansemal District, Badung Regency, with an area of 450 hectares, with a population of 4,367 people. Sangeh Village is a tourist destination because it has a natural tourist attraction in the form of a nutmeg forest with monkeys and a temple and a sacred area of Pura Pucak Sari. In addition, Sangeh Village also has a recreational park, Taman Mumbul spring which will be developed into a spiritual and 
spiritual tourism area. To support this tourism, Sangeh Village is currently promoting culinary tourism. In the financial sector, Sangeh Village is supported by the People's Credit Bank, namely PT. Ban Desa Sangeh and Village Credit Institution (LPD) of Sangeh Traditional Village, as well as licensed cooperatives, which as a whole manage assets of Rp. 97. 184.733.8 (Ninety-seven billion one hundred eighty-four million seven hundred thirty-three thousand eight hundred and forty-eight rupiah). LPD is one of the fast growing Micro Finance Institutions in Bali Province, especially in Badung Regency. The LPD is one of the institutions at the Traditional Village level. Its existence so far has been proven and its benefits are greatly felt by the Krama Desa Adat (Saputra, Trisnadewi, Anggiriawan, \& Kawisana, 2019) (Gunawan, 2009). Until now, the LPDs in all of Bali Province were established only in view of Bali Territory Local Guideline (Perda) Number 4 of 2012 concerning the Second Amendment to Perda Number 8 of 2002 concerning LPDs, and are under the supervision of the Regional Government Bank (BPD) of the Province of Bali. Small and micro entrepreneurs prefer LPD over formal financial institutions as back up finance in their business. That added value then makes LPDs in Bali superior to existing formal financial institutions.

As previously explained that in Sangeh village, apart from the LPD, there is also a People's Credit Bank. According to Law Number 10 of 1998 concerning banking, article 1 paragraph (2) determines that a Rural Bank is a bank that carries out business activities conventionally or based on sharia principles which in its activity does not provide payment traffic services. People's Credit Bank business activities are aimed at serving small businesses and communities in the regions. Rural Banks are in the form of Limited Individuals, Regional Companies or cooperatives. BPR Sangeh was originally established to work together with the LPD under the Adat village.

The existence of BPR Sangeh as a formal financial institution in Sangeh village apart from the LPD in Sangeh Village and the cooperative in Sangeh Village, was originally intended to help and work hand in hand in providing savings and loan services in Sangeh village. However, if the legality of BPRs is examined in accordance with OJK Regulation Number 20 / POJK.03 / 2014 concerning Rural Banks in Article 4 paragraph (1), it is determined that:

BPRs can only be established and owned by Indonesian citizens, Indonesian legal entities whose owners are all citizens the Indonesian state, and or local government.

Of course, the provisions of the article mentioned above are not in accordance with the establishment and ownership of BPR Sangeh which is owned by an Adat village, and an Adat village is not a legal entity. The problems experienced by partners are the need for an academic study of the legality of BPRs managed by Traditional Villages and a lack of understanding of the legality of BPRs managed by Traditional Villages and the need for the existence of LPDs in Sangeh Traditional Village, Abiansemal District, Badung Regency.

A number of relevant research have been carried out, one of them is about the role of the village credit institution (LPD) in providing services to the legian village community is studied by Agustini (2019). Furthermore, village credit institutions as a support for the continuity of the Balinese economic culture is examined by Sadiartha (2017). Finally, Sundarianingsih (2014) studied the evaluation of the success of the village credit institution (LPD) in mobilizing the socio-economy of rural communities.

The problems mentioned above will be answered through community service with the concept of drafting village regulations on strengthening the existence of the LPD as a traditional village financial institution. 


\section{Literature Review}

In 1988 the local government of Bali Province confirmed the ownership status of the Village Credit Institution as belonging to customary villages. This is stated in the Bali Provincial Regulation Number 2 of 1988 concerning Village Credit Institutions, which states that the Village Credit Institution is a Traditional Village Owned Savings and Loan Business Entity. Then it was updated in the Bali Provincial Regulation Number 8 of 2002 concerning Village Credit Institutions (Suryanata, 2018), which was further updated again in the Regional Regulation of the Province of Bali Number 3 of 2007, and renewed again into the Regional Regulation of the Province of Bali Number 4 of 2012 (hereinafter referred to as Perda Village Credit Institutions), Article 1 point 9 determines that the Village Credit Institution is a VillageOwned Financial Institution located in the Village.

The characteristics of the Village Credit Institution which are emphasized in the Perda are that the Village Credit Institution is a financial institution belonging to the Pakraman village which is based on the regulations that apply to the Pakraman village (awig-awig) (Utari, Sara, \& Giri, 2019). Ownership by the Pakraman village is expected to strengthen the Village Credit Institution as a village credit institution to help people maintain their traditions and customs. Pakraman village has a awig-awig (regulation) that has power in the community so that the Pakraman village is considered appropriate to own and control the Village Credit Institution.

The performance of the Village Credit Institution adopts banking management administration that is fostered by the Bank Development Bali Regional. The Village Credit Institution's business field includes receiving/collecting funds from the krama village in the form of savings and deposits and providing loans only to krama village, not outside public funds such as banks in general. This is because the Village Credit Institution is not only profitoriented, but for the welfare of the boarding school village as a whole.

Today, Village Credit Institutions have shown very rapid development, both in terms of numbers and in terms of business development. As a microfinance institution, the Village Credit Institution has played a significant role in encouraging economic development and creating business opportunities for rural communities, as well as participating in government programs to alleviate poverty in Bali.

The Village Credit Institution has a very strategic role because so far it has served Micro, Small and Small Enterprises (hereinafter referred to as UMK) and rural communities in Bali through financial services carried out according to customer needs, namely simple procedures, short processes, personal approaches and proximity to locations. with customers. What is unique about the Village Credit Institution in Bali is that on the one hand the Village Credit Institution is based on the community Pakraman village and is based on customary law, but on the other hand the administrative performance of the Village Credit Institution adopts banking management.

BPRs have existed since before independence. At that time, BPR was better known as the Village Bank, Lumbung Desa, Bank Tani and Bank Dagang Desa or Bank Pasar. According to Law Number 10 article 1 paragraph 2 of 1998 concerning banking, it determines that a Rural Bank is a bank that carries out business activities conventionally or based on sharia principles which in its activity does not provide payment traffic services. People's Credit Bank business activities are aimed at serving small businesses and communities in the regions. Rural Banks are in the form of Limited Individuals, Regional Companies or cooperatives. 
Bank Perkreditan Rakyat is a bank that has limited business activities with simple transactions, including raising funds in the form of savings, time deposits and lending. This limitation is given to Rural Banks in relation to the main service objectives of Rural Banks for micro, small and medium enterprises and the surrounding community. Bank Perkreditan Rakyat is one of the supporters of the development of the Indonesian economy, especially for micro, small and medium enterprises. The role of rural banks in providing credit for micro, small and medium enterprises can help create jobs, equal income distribution, and equal business opportunities in Indonesia. Likewise with the LPD, is not only useful according to its function, but also creates jobs (Kurniasari, 2007).

\section{Research Method}

Table 1. Action Plan

\begin{tabular}{|c|c|c|c|}
\hline No. & WorkActivity Plan & Approach Method & Procedure \\
\hline 1. & $\begin{array}{l}\text { Preparation of academic } \\
\text { studies on the legality of } \\
\text { BPRs managed by Adat } \\
\text { villages. }\end{array}$ & $\begin{array}{l}\text { a. Mapping the potential of } \\
\text { financial institutions in } \\
\text { customary villages; } \\
\text { b. Observing juridical issues } \\
\text { regarding the legality of } \\
\text { financial institutions } \\
\text { managed by customary } \\
\text { villages. }\end{array}$ & $\begin{array}{l}\text { a. Conducting interviews } \\
\text { with partners. } \\
\text { b. Provide technical } \\
\text { guidance to village heads } \\
\text { and BPR Directors who } \\
\text { will participate in } \\
\text { compiling academic } \\
\text { studies. }\end{array}$ \\
\hline 2. & $\begin{array}{l}\text { Disseminating } \\
\text { information about the } \\
\text { legality of BPRs managed } \\
\text { by traditional villages and } \\
\text { the existence of the LPDs } \\
\text { as village financial } \\
\text { institutions. }\end{array}$ & $\begin{array}{l}\text { Approach with village officials } \\
\text { and village BPR Directors Adat } \\
\text { Sangeh. }\end{array}$ & $\begin{array}{l}\text { a. Dissemination of laws } \\
\text { and regulations } \\
\text { governing the } \\
\text { establishment and } \\
\text { ownership of BPRs. } \\
\text { b. Socialization of the } \\
\text { importance of the } \\
\text { existence of LPDs as } \\
\text { financial institutions in } \\
\text { traditional villages }\end{array}$ \\
\hline
\end{tabular}

\section{Results and Discussion}

\subsection{Performance of the Warmadewa University Community Service Institute}

Universities in Indonesia are expected to be able to carry out research results in the form of community service in accordance with the potential for regional excellence. Bali as one of the world's tourist destinations also has the largest private university. The vision and mission of the organization are quality, integrity and environmental awareness. The key arrangement figured is an expert instructive foundation that is prepared to contend at the public and worldwide levels in 2034. It has 7 examination programs (Faculty of Agriculture, Medicine, Engineering, Economics, Law, Social Sciences, arts) and 1 Postgraduate and understudies adding up to $8,500,000,000$ individuals. Driving institutional examination assembled is arranged towards a travel industry based climate (Green eco-the travel industry). The improvement of the logical field depends on the Tri Hita Karana idea which is taken from the social way of thinking of the individuals in Bali, specifically the demeanor of compassion 
towards individual people, nature and the Supreme Creator which is showed as network administration.

With regard to the main tasks and functions, the Warmadewa University (LPM) community service institution has carried out several activities are financed by the University, government and in collaboration with other parties. Budget and acquisition of grants continued to up, in 2010 the Directorate of Higher Education managed to obtain 5 dedications in young form lecturers, women's studies, and competitive grants. In 2016, 16 service recommendations and 15 between sectoral research were passed, financed by a foundation of IDR 160,000,000. In 2017, he got institutional assets of IDR 250,000,000, per gathering of IDR 12,500,000. An aggregate of 21 exploration and administration recommendations have passed the Dikti Grants.

In the field of service which is incidental, LPM holds community service activities every year in collaboration with government partners, private sector and community groups that are jointly funded, in the form of inter-sector service and the Assisted Villages. The assisted village that has been in launched is Pinggan town in Kintamani sub-area, Bangli locale. In Karangasem Regency with 8 sub-locale, 38 towns with the KKN program: finishing ignorance, investigating the travel industry potential, applying fitting innovation, network strengthening.

So as to improve quality and amount. Administration service institutions LPM organizes training and assistance in making proposals by inviting a reviewer team from the Higher Education, also organizes internal reviewer training. Arranging a national seminar on journal made with international reputation, delegate several lecturers to participate in international level conferences as presenters of scientific work in 2016 and developing business incubators to accommodate the products of the fostered villages. The existence of a Head of Women's Study Unit. Ka. Environmental unit, Ka, cultural studies unit.

In order to develop the scientific field and make a real contribution to society and to provide solutions based on academic studies of the needs or problems faced by the community, community service is carried out in Sangeh Village, Abiansemal District, Badung Regency, regarding the existence of the LPD as a traditional village financial institution.

\subsection{Field of Facilities}

Supporting facilities for the tri dharma program owned by institutions like: biological laboratories, physics laboratories, chemistry laboratories, wet laboratories, dry laboratories, medical laboratories, technical laboratories, language laboratories, legal aid laboratories and moot courts and social science and political science laboratories. So as to give great affirmation. In accordance with the advancement of science and innovation and the increasing and varied needs for labor competency in the labor market, in the following five years, Warmadewa University intends to build up a few things, namely:

a. Revitalizing laboratory / workshop facilities in each study program as a support quality of service and graduates

b. Developing libraries into libraries based on IT (e-library) so as to facilitate current access to science and technology,

c. Developing Competency Test Points (TUK) in each department to

d. Improve the nature of learning offices (learning media).

\subsection{Field of Infrastructure}


The Availability of infrastructure that is owned by Warmadewa University which is utilized by study programs from the part of ampleness is considered sufficient as per the requirements of the fitness and profile of each examination program, nonetheless, it is in accordance with the desires of the establishment in the following barely any years which looks to improve amount and nature of administration, it is as yet esteemed important to keep including new framework.

In terms of reasonableness, Warmadewa University still considers it necessary to keep on creating. This advancement is identified with the pertinence of administration to the requirements of the business and in accordance with the improvement of science and innovation. The elements of the advancement of mechanical needs and the improvement of science and innovation are the premise of reference for institutions in maintaining keeping up the reasonableness and sufficiency of the foundation that must be given in study programs. The improvement plan in the following five years for framework will carry out infrastructure development by looking at the competency needs and existing technological developments. Development will be carried out in relation to the requirements of the investigation program on the accessibility of framework in classrooms, laboratories, and needs for workshops. The development targets in foundation are the expanding nature of administration results, quality assistance to explore and the importance of research competencies.

\section{Conclusion}

Based on OJK Regulation Number 20 / POJK.03 / 2014 concerning Rural Banks in Article 4 paragraph (1) it is determined that BPRs can only be established and owned by Indonesian citizens, Indonesian legal entities whose owners are all Indonesian citizens; and / or Local Government, from the provisions of the article mentioned above, it is not in accordance with the establishment and ownership of BPR Sangeh which is owned by an Adat village, and the Traditional village is not a legal entity.

If analyzed from the Bali Provincial Regulation Number 8 of 2002 concerning Village Credit Institutions, then it is further updated again in the Regional Regulation of the Province of Bali Number 3 of 2007 and updated again to the Regional Regulation of the Province of Bali Number 4 of 2012, Article 1 number 9 determines that the Village Credit Institution is an Institution Village Owned Finance located in the Village. The characteristics of the Village Credit Institution which are emphasized in the Perda are that the Village Credit Institution is a financial institution belonging to the Pakraman village which is based on the regulations that apply to the Pakraman village (awig-awig). Ownership by the Pakraman village is expected to strengthen the Village Credit Institution as a village credit institution to help people maintain their traditions and customs. Pakraman village has a awig-awig (regulation) that has power in the community so that the Pakraman village is considered appropriate to own and control the Village Credit Institution.

Based on the regulations that apply to the pakraman village (awig-awig), the output to be achieved is full ownership by the Pakraman village of the Sangeh Traditional Village through the formulation and decisions of the traditional village in (awig-awig) by integrating the assets of BPR Sangeh into the LPD of the Traditional Village Sangeh to strengthen institutional finances and provide legal certainty for the status of traditional village financial institutions in order to assist the community in growing and developing the economy of the Sangeh Traditional Village community. 


\section{References}

[1] Agustini, M. E. (2019). Peran Lembaga Perkreditan Desa (LPD) dalam Memberikan Pelayanan pada Masyarakat Desa Legian. Jurnal Ilmiah Dinamika Sosial, 3(2), 279291.

[2] Gunawan, K. (2009). Analisis Faktor Kinerja Organisasi Lembaga Perkreditan Desa di Bali (Suatu Pendekatan Perspektif Balanced Scorecard ). Jurnal Manajemen Dan Kewirausahaan, 11(2).

[3] Kurniasari, T. W. (2007). Lembaga Perkreditan Desa (LPD) dalam Perspektif Hukum: Sebuah Lembaga Keuangan Adat Hindu Penggerak Usaha Sektor Informal di Bali. Jurnal Masyarakat Dan Budaya, 9(1), 53-78.

[4] Raydika, I. D. G. Z. (2013). Kedudukan Hukum dan Kinerja Lembaga Perkreditan Desa (LPD) Pakraman di Bali dalam Sistem Lembaga Keuangan Mikro Menurut Undang-Undang Nomor 7 Tahun 1992 Tentang Perbankan (Studi di LPD Desa Pakraman Kedonganan, Kabupaten Badung). Universitas Brawijaya.

[5] Sadiartha, A. A. N. G. (2017). Lembaga Perkreditan Desa sebagai Penopang ke-ajegan Budaya Ekonomi Masyarakat Bali. Jurnal Kajian Bali, 07(02), 1-18.

[6] Saputra, K. A. K., Trisnadewi, A. A. A. E., Anggiriawan, P. B., \& Kawisana, P. G. W. P. (2019). Kebangkrutan Lembaga Perkreditan Desa (LPD) Berdasarkan Analisis Berbagai Faktor. Jurnal Ilmiah Akuntansi, 4(1), 1-23.

[7] Sundarianingsih, P. (2014). Evaluasi Keberhasilan Lembaga Perkreditan Desa (LPD) dalam Menggerakkan Sosial Ekonomi Masyarakat Pedesaan (Studi pada Lembaga Perkreditan Desa (LPD) Desa Adat Pekutatan). Jurnal Ekomomi Pembangunan, 12(1).

[8] Suryanata, I. G. N. P. (2018). Pengaruh Faktor Eksternal dan Internal terhadap Kinerja Lembaga Perkreditan Desa (LPD) serta Dampaknya bagi Loyalitas Masyarakat Desa (Studi pada LPD di Kabupaten Badung Bali). Juima, 8(2), 95-106.

[9] Utari, N. K. M. T., Sara, I. M., \& Giri, N. P. R. (2019). Pengaruh Pertumbuhan Aktiva Produktif, Dana Pihak Ketiga dan Ukuran Perusahaan terhadap Profitabilitas Lembaga Perkreditan Desa (LPD) di Kecamatan Mengwi. Warmadewa Economic Development Journal, 2(2). 